\title{
The tourism and travel industry and its effect on the Great Recession: A multilevel survival analysis*
}

\author{
Zdravko Šergo' ${ }^{1}$ Jasmina Gržinić ${ }^{2}$ Mirela Sučić Čevra ${ }^{3}$
}

\begin{abstract}
Does a country with a heavy dependence on a tourism economy have a tendency to succumb to more risk in a recession? With the shift from manufacturing-based economies in the developing world toward service-based industries, including tourism, a reliance on the tourism industry may erode economic stability in tourism-based countries, making them more prone to fall into a recession due to higher risks. In this paper, we wish to emphasise the positive impact of tourism specialisation indices in the international economy on the probability occurrence of a so-called Great Recession. This article uses a multilevel survival analysis and a generalised linear mixed-effect (GLMM) structure modelling to investigate the impact of tourism development on the probability of recession frequency (risk in terms of months of duration and severity), by using data collected from 2007 to 2013 from 71 countries around the world, to see if recession frequency is positively correlated with the various indicators of tourism development. Two GLMMs were fitted to this data: logistic regression and count regression with a Poisson distribution. Results for both regressions show considerable evidence that the ratio between the number of overnight stays and the resident population and travel services as a percentage of commercial service exports positively impacts the probability for a country (from our sample) to experience a recession event and can make recession worse in terms of severity, measured in months.
\end{abstract}

Key words: Recession, duration, risk, tourism, multilevel survival analysis, GLMM

JEL classification: $O 1, F 6$

\footnotetext{
Received: 7-03-2017; accepted: 21-12-2017

1 PhD, Senior Research Associate, Institute of Agriculture and Tourism Poreč, Karla Huguesa 8, 52440 Poreč, Croatia. Scientific affiliation: macroeconomics and applied econometrics, economic growth. Phone: +38552408300.Fax:+38552431659.E-mail: zdravko@iptpo.hr (corresponding author).

2 Full professor, University Jurja Dobrile in Pula, Faculty of Economics and Tourism "Dr. Mijo Mirkovic’”, 52100 Pula, Croatia. Scientific affiliation: tourism development, international tourism, tour operators and travel agencies. Phone : +38552377 029. Fax: +38552 216416. E-mail: jasmina.grzinic@unipu.hr.

${ }^{3}$ PhD, Tumlare Corporation, 10000 Zagreb, Croatia. Scientific affiliation: destination management, tour operators and travel agencies. Phone:+3851483 0337. Fax: +3851483 0067.E-mail: Mirela.Sucic@tumlare.com.
} 


\section{Introduction}

By definition, a country is in recession when it has experienced two quarters of negative GDP growth; in fact, a recession can be defined as a market failure that causes a persistent and substantial increase in unwanted idleness. A recovery period follows a recession, during which idleness returns to normal levels. Business cycles have been one of the less studied and discussed topics in seminal economics literature prior to the Great Recession that began in 2007. Prior to 2007, there was less need for deep study of irregular short-term variations in production, employment or the stock market. Indeed, the period from the end of the disinflation in the mid-1980s to 2007 was one of unprecedented macroeconomic stability in the United States - from where the financial crises in 2008 propagated recessions around the world. The United States went through only two recessions in this period, both of them mild (Romer, 2012: 644). One of the leading explanations of the Great Moderation period was the change in the structure of the economy, demonstrated by things such as the larger role of services and improvements in inventory management (McConnell and Perez-Quiros, 2000; Ramey and Vine, 2004). Another contributor was the improved policies that came with the triumph of the natural-state hypothesis and the emergence of a consensus that inflation should be kept low (Romer, 1999). And a third was simply good luck, in the form of smaller shocks hitting the economy (Stock and Watson, 2003).

This period of stability ended dramatically in 2008 - although whether the end was temporary or permanent is not yet known. A vast amount of literature on the subject since 2008 avails our knowledge and provides widely-accepted conclusions about the cause of the financial recession in the US. Studying the perils of the recession from different angles is less present in recent research. This paper tries to fill a bit of this gap and studies the differences across countries in post-recession recovery times in terms of tourism activity. This is, to our knowledge, the first formal empirical approach to the subject that incorporates information about tourism and recession/recovery events of a heterogeneous set of countries. Our analysis does not look for a reduced model containing the elements that explain and prevent recessions. Its scope is simpler and, at the same time, more pragmatic; the task in this paper is to not try to figure out what causes a Great Recession in general, but to predict recession probabilities for a wide set of countries with regressors that encompass tourism intensity. We hope that identifying the variables that stem from the complexities of tourist activity and that influence, in a robust way, the expected length of a recession can be of great value to policy-making in those countries.

The main positive economic impacts of tourism development on human well-being and economies relate to foreign exchange earnings, contributions to government revenues, and generation of employment and business opportunities, and so on. The consequences of tourist expenditure are tourism receipts, in other words, multiplied 
income to residents of the tourism destination. We can discuss the consequences of the positive aspects of tourism growth and development by researching the tourismled growth hypothesis, in a narrowly empirical sense. However, this is not our ambition. Instead of a long-term growth time span, the following analysis concerns only the length of the Great Recession (2006-2013). Namely, the focus in this paper is on a short-term variation in growth (i.e. recession) and its relationship to tourism intensity.

The main hypothesis of the research is: that a country which is heavily dependent on a tourism-based economy has a tendency to succumb to more risk in a recession. The following research question is asked in this paper in an effort to analyse the main problem of: whether the presence of tourism and its strength in a national economy explain and predict the probability that a hypothetical country has experienced the problem of a Great Recession.

The goals of this paper lie in a meticulous elaboration of the main hypothesis, a proposal of an econometric model and an eventual proving or rejection of the main hypothesis in the empirical part of the paper.

The paper is organised as follows. The next section begins with a literature overview and then maps out a research strategy, including the conceptual framework, the dataset, the model specification and the variables. The subsequent section presents and discusses the empirical results, and the final section concludes by providing implications for economic policy and further research.

\section{Literature review}

Reviewing more recent literature about tourism and its effect on the recent recession, it has been found out that in comparison to this research, previous studies have been limited to statistical analysis of the impact of the Great Recession on tourism and does not consider the situation in a vice versa sense to address the impact of tourism on the Great Recession. It is not yet known, from the previous research, what impact tourism dominance can have during recession on a global environment.

In the existing tourism literature, the application of quantitative methods to the relationship between the Great Recession and tourism addresses almost exclusively the impact of recession on tourism demand, competitiveness, or expenditures.

Drawing on an analysis of the macroeconomic effects of the global recession and its impact on tourism demand for outbound travelling in Australia, Canada, the United States, Japan, and the EU-15 countries, one study developed forecasts for the period from 2009 to 2010 (Smeral, 2010). In 2008-2009, the challenging economic environment and stock market volatility had a negative impact on 
tourism in terms of wealth generation, job creation and economic diversification for many economies worldwide (Chan and Lim, 2011). According to Murgoci, et al. (2009), when nations face a global credit crisis, fluctuating stock markets, erratic fuel prices, and a global recession, people and businesses begin to reduce travel and businesses are scaling back their travel budgets. One study considered the influence of business cycles and economic crises on Spain's tourism competitiveness and came to the conclusion that the effects of the economic shocks are not neutral on competitiveness, with the negative effects being more persistent in highly intensive crises (Perles-Ribes et al., 2016). Alegre and Pou (2016) examined US household tourism expenditure patterns over the last business cycle, by applying a Heckman model to microdata drawn from the Consumer Expenditure Survey for the period of 2005 to 2012. Eugenio-Martin and Campos-Soria (2014) proved that during an economic crisis, tourists' decisions to cut back on tourism expenditures depend on the climate conditions of the place of origin, the GDP and GDP growth.

Other studies have focused on topics such as the price elasticities of tourism demand in the Great Recession time span and the economic resilience of the tourism sector of a particular national economy in the years of the Great Recession. Callaghan and Tol (2013) applied a pooled travel cost model for UK travellers to estimate the price elasticities of tourism demand for various market segments in the Great Recession time span and found that a reduction in the travel tax and a reduction in the VAT rate for "tourism goods and services" would lead to a modest increase in visitor numbers and expenditures. Ritchie et al. (2010) show that tourism in Canada and the United States has been, and is being, affected by the current economic crisis, and it appears likely that it will be further affected in the near future. In contrast, tourism in Mexico has been affected more directly and to a much greater extent by the swine flu pandemic, exchange rates, and weather conditions than by the economic crisis itself. Cellini and Cuccia (2015) compute an index to capture the economic resilience of the tourism sector in various Italian regions, and propose an exploratory analysis to understand its relationship with structural characteristics and strategies across regions. Their interpretation is that deep structural changes in the demand and supply side of the tourism industry, rather than specific adjustments, have occurred in the years of the Great Recession. A paper by Poudyal et al. (2013) applied a generalised method of moments (GMM) estimator to monthly data of U.S. National Park visitations to evaluate the effect of the recession on visitation. Results indicate that recession, regardless of the macroeconomic measure used, was negatively associated with demand to visit national parks. In regard to tourism demand, tourists from different European regions have reacted heterogeneously during the Global Economic Crisis. Such variability is due to different preferences and willingness to pay for tourism (Eugenio-Martin and Campos-Soria, 2014).

Taking all into consideration, after perusing the recent empirical literature related to the problems of the tourism - Great Recession nexus, we state that the specific area 
of research addressed in this paper - the perspective of the effect of tourism on a recession - has been overlooked, or better said, has been neglected.

We proceed with a theoretical narrative about the centre - periphery model applied to tourism from the literature (Candela and Figini, 2012: 218-238) and then relate it to a profit margin theory of business cycles (Mitchell, 1927).

A model that provides many insights into the understanding of international flows is the centre-periphery model (Krugman, 1991, Krugman and Venables, 1995). The model, by Candela and Figini (2012) applied to the case of tourism in a simplified way, proposes an endogenous interpretation of the localisation of tourism from the movement of tourists in a centre-periphery setting. In their analysis, they introduce the linear cost function that shows economies of scale along the variable, fixed and average cost analysis as production and tourism demand increases. The centreperiphery model, at the end, shows that regions can assume many configurations in equilibrium; there are countries that become international tourism destinations and in which incoming tourism constitutes the most relevant part of tourism flows; there are countries that become the tourism periphery, where outgoing tourism constitutes the main part of tourism flows; and finally, there are countries with an integrated tourism system, in which outgoing and incoming tourism coexist with domestic tourism. The issue of localisation in a global framework remains history driven; small accidental events give life to a cumulative process that, starting with a few firms, develops and attracts other firms and workers, and evolves with the concentration of an increasing number of firms and workers that react to the economic incentives provided by that localisation.

Mitchell's theory of business cycles applied to tourism destinations can help to illustrate this. Economies of scale and the external economies of production explain the growth of a tourism country, but at the beginning of the process, history and chance play the most relevant roles. Economies of scale come from investment, primarily in construction and housing. Namely, investment in housing is driven by the expected profits, or profit margin, which is simply the price minus the average cost of the good. That good can be an apartment, a larger hotel or other type of housing and the trajectory path of selling those items is uncertain. Economic variables are well connected, affecting each other cumulatively over time. For example, housing prices depend on current and past prices and have a tendency to inflate in good times and consumption depends on current and past incomes. It is well known that overinvestment in a tourism destination is caused by a housing bubble. A developer depends on present and prospective profits, and profits increase when investments in housing rise. These variables are microeconomic and macroeconomic that are grounded in money and banking, technologies and innovations, stock markets in the tourism destination. Mitchell (1927) argued that profit margins are strongly procyclical in an imperfect competitive market because costs fall during expansion. This happens for a number of reasons; we will try to 
find linkages of those reasons in regard to tourism. First, manufacturing firms are able to reduce their inventories, thereby reducing costs. However, non-tourism businesses are crowded out in typical tourism destinations. This can take place when, due to scarcity of spatial resources, the development of a tourism project uses resources that cannot be used in other manufacturing processes. The crowding out can unfold in the credit market or in the use of real resources, such as land (For more see Prud'homme, 1985). Second, input cartels tend to fall apart during recessions, so the beginning of expansions should be characterised by lower input prices. In the condition of poor industry due to a crowding out effect in a tourism destination, the recovery is slowed down. Finally, a larger tourism supply means that economies of scale can be exploited. Economies of scale refer to conditions when the average cost of service falls as the quantity of service produced rises. Economies of scale tend to exist in industries with large fixed costs, because higher production allows these fixed costs to be spread out over more units, reducing the average cost. Yet, in tourism, the size of capital (for example, units of a hotel in terms of number of rooms), as a rule, fluctuates according to the season. It becomes impossible to store production (hotel rooms) as inventory during the low season. This is derived from the following consideration: tourism is a service and a service, no matter what its value, cannot be stored: it is not possible to produce and stock services (like hotel rooms or restaurant seats) in periods of low demand to sell them when the demand is higher. Furthermore, in tourism destinations, seasonal fluctuations (unlike cyclical fluctuations) generally conform to a steady pattern (ski tourism and sun and sea tourism are mainly mono-seasonal). A country in which tourism is the dominant sector among others builds its capacity in order to satisfy mass tourism demand or high peak demand. With this very often comes a construction boom and a housing bubble, as we rationalised above. For example, Spain, as a top tourism destination, has experienced an extreme housing bubble in recent years, according to Mauldin and Tepper (2011). In fact, Spain has as many unsold homes as the US, even though the US is about six times bigger.

Procyclical movements in the profit margin feed expansions and magnify contractions in a tourism-focused country. This can be substantiated by the following. According to Kaldor's model of the distribution of total income and wages, a destination with a higher share of tourism in its economy, or one with the features of a tourism destination, has a higher quota of profits and a lower quota of wages in its national income (Candela and Figini, 2012: 449). Contractions and expansions are profit driven in a tourism economy. During good times, rising profit margins increase profits and encourage firms to undertake investment projects. The probability of this in a tourism destination could be much higher than in a country that belongs in the tourism periphery. However, these projects do not immediately increase the capital stock and capacity. In the meantime, a construction bubble can explode as the economy rises and profit margins begin to fall. Falling profit margins reduce accepted profits and reduce a firm's likelihood of undertaking new 
investment projects, eventually turning an expansion into a much worse contraction than seen in a country of tourism periphery. Overconfidence of investors in the tourism country disappears, and pessimism prevails.

Many important studies are available in the literature about Mitchell and his general business cycles but none are applied particularly to the tourism sector. The historical overview of those studies is wide: Homan (1928), Schumpeter (1930, 1939 and 1950), Hansen (1949), Mills (1949), Kuznets (1949), Koopmans (1947), Friedman (1950), Lucas (1980), Kydland and Prescott (1990), Sherman (1991), and Sherman and Kolk (1996) all provide various views and critiques about Mitchell's work on the business cycle. The most damaging view of Mitchell's theory of the business cycle was presented by Koopmans (1947), who criticises measurement without theory. He criticised Burns and Mitchell (1946) by arguing that collection of data and statistical analysis were performed without having a theory in mind.

The model that we are attempting to apply is an atheoretical one, in some sense. In defines of a complaint like Koopmans', we can paraphrase Lindert (according to Bruner, 1981: 125) inserting "Recession" in place of "Depression", saying, "explaining the onset, the severity, and the duration of the Great Recession is almost as central a task to macroeconomics as is the study of viral epidemics to medicine".

\section{Conception of the analysis}

\subsection{Theoretical framework}

Next, we can form a conjecture that recession episodes are heavier and more prolonged in a country that becomes an international tourism destination and build some premises in regard to this idea.

Our task later on is to draw a conclusion on the basis of data analysis in the very short time span of recent history that embraces the Great Recession.

Before a statistical analysis examining the relationship between recession and the various variables linked to the tourism and travel industry can be performed, some geolocation variables identified as affecting the probability of recession in our presumption need to be addressed.

We will distinguish between a conceptual model and the model we actually use for the estimate. One can model the probability for recession in any one destination theoretically with the help of the following function:

$$
R=f(-M,+E,+S,+I,+T,+C,+A)
$$


where $R$ represents recession; $M$ is the duration of the recession; $E$ is the relevant characteristic of the tourism destination, such as direct tourism employment, $S$ is tourism saturation; $I$ is tourism receipts in the destination; $T$ are the travel services to reach the destination; $C$ is the destination's general attractiveness to tourists proxied by coastal borders; and $A$ is the air traffic. The sign before each variable signals its expected effect on recession probability. Such a formulation is in line with the aforementioned general consideration on the link between tourism destinations and the behaviour of business cycles.

We should say, risking losing needed relevancy, that our preceding empirical exercise on the grounds elaborated is not an attempt to verify some hard theory, but is rather a modest attempt to test the relationship between the Great Recession and tourism.

\subsection{Econometric model}

Given the probable complexity of the relationship between recession frequency and severity and the hypothesised correlations, simple linear multiple regressions and stepwise model building were considered inappropriate. We instead use a multilevel model, inferential approach based on information theory (Burnham and Anderson, 2002) to construct a limited a priori model set to examine the major hypotheses. The model building strategy was based on the following logic:

The number of recessions experienced in any one country should depend on: 1) direct contribution of travel and tourism to employment as a percentage of the overall economy employment; 2) the total international tourism receipts as a percentage of total exports (i.e. the less monetary receipts from other sources -mainly export of goods - the higher total frequency of recession); 3 ) the average saturation per capita generated by tourism flows in the country; 4) the amount of travel services as a percentage of commercial service exports, which covers goods and services acquired from an economy by travellers in that economy for their own use during visits of less than one year for business or personal purposes. Travel services include the goods and services consumed by travellers, such as lodging and meals and transport (within the economy visited); 5) attractiveness, measured by the ratio of the length of the coast to full border circumference, 6) air transport per capita, measured by air passengers divided by the total population. Air passengers carried include both domestic and international aircraft passengers of air carriers registered in the country. As such, all models considered these four covariates as 'control' variables. In addition, (7) the spatial regime of a given country is considered as a random factor (European/NonEuropean) for all models considered (see the model structure below). And finally, (8) we reasoned that total tourism receipts in total exports and amount of travel services in service exports (between 2006 and 2013) would not influence recession frequency in a mutually exclusive fashion, considering that the 'natural' condition of a country 
may have varying tourism intensity for reasons independent of tourism activities; therefore, both co-variates were considered simultaneously in certain models, with an interaction between them considered plausible given that recession frequency may also depend on those interactions. The random effects structure corrects for non-independence of statistical units (countries) due to similar spatial regimes of belonging to a certain circle of countries (EU or non-EU).

Data was introduced into a multilevel survival analysis using $\mathrm{R}$ mixed models. Multilevel analyses in general are advisable when there are two (or more) levels of analysis, with one level (here, individual country) nested in level two aggregates (here, wider spatial geolocation of countries). Using this research method allows us to exclude the variability between higher units (geolocation) when observing the variability of subordinate levels (country). It therefore leads to more accurate results when independent variables are analysed at both the individual and the wider geolocation level (for a detailed description of multilevel analysis see Hox, et al., 2010). Multilevel analysis (MLA) distinguishes between the individual level (country) and the spatial level (European and non-European country).

Recession risk is a right-censored characteristic in this sample, because some of the countries experienced their recessions during and after the time span of the analysis (some were ended by 2013). For those countries, the recession is not considered in our analysis to be over. Thus the correct view of the individual countries and aggregates is that the final outcome (recession or not) is not yet established. The recommended mode of analysis for right-censored observations is event history analysis, also known as survival analysis (Singer and Willet, 1993). Thus, this analysis is a combination of multilevel and event history analysis. The combination of recession/duration in months/tourism indicator is the lowest level, the observation on a country level is the next level, and the aggregate level is the highest level. To analyse this data, the data file is restructured into a three-level data structure: aggregates, country nested within geolocation families, and recession/ months nested within country. The series of recession/months ends either with an observed recession or as a right-censored variable. The lowest level can be conceptualised as a series of independent trials in which the event does or does not occur. This results in a discrete-time analysis; in each discontinued or unequal time interval $t$, we observe a binary response variable that indicates whether recession occurred. This representation allows us to use models for binary response variables in a multilevel context (Hox et al., 2010).

We make the usual assumption that the censoring is non-informative, meaning that the censoring mechanism is not related to the time-to-event. The hazard function $\mathrm{h}(\mathrm{t})$ is the probability of the event occurring in interval $\mathrm{t}$, conditional upon no earlier occurrence. In our case, the time variable $t$ is the length of the recession at time t. The hazard is modelled using a logistic regression, as the first regression, in the following form: 


$$
\log i t\left(h_{i j(\mathrm{t})}\right)=\alpha(t)+\beta x_{i j(t)}+\beta z_{j}+u 0 j
$$

In this equation, $\alpha(t)$ is the baseline hazard at recession-month in discontinued time interval $t, x_{i j}$ represents the country-level predictors, and $z_{j}$ represents the geolocation level predictors. The value of $u 0 j$ incorporates the aggregate level residual errors; since this is a logit model for binary outcomes, there is no countrylevel error term (cf. Hox et al., 2010). The regression coefficient $\alpha$ for the effect of recession length may or may not vary across individual countries or aggregates (European or non-European country); in our case, there was a between-aggregate variation that disappeared when all available predictors were included in the model. The regression coefficients $\beta$ for the geolocation-level predictors may or may not vary across aggregates. In our case, there was no higher-level variation of these regression coefficients; consequently, in Eq. (1) they carry no subscript for two spatial aggregates.

In the Poisson regression model the number of recession events expressed in months has a Poisson distribution with a conditional mean that depends on an individual country's characteristics:

$$
\mu_{i j}(t)=E\left(y_{i j(t)} \mid x_{i j(t)}, z_{j}\right), \text { or } \mu_{i j}(t)=\alpha(t)+\beta x_{i j}(t)+\beta z_{j}+u 0 j
$$

Since the dependent variable of second regression is a count, and that is the number of months that span a recession event in a country, Poisson regression is appropriate. Otherwise, that regression has as response a variable duration of the recession and is fitted also within a multilevel GLMM structure.

Both models were estimated using the lme4-package adopted by $\mathrm{R}$ software for statistical computing (Bates et al., 2015). The relatively low sample size (71 countries) necessitated an analysis considering no more than nine models per response variable. The estimation method used was the maximum likelihood (Laplace approximation) for binary data with asymptotic standard errors for significance tests of separate parameters; and generalised linear mixed models (GLMMs) for Poisson distributions. Because this is often not very reliable in small samples (this sample is 272 observations), we re-estimated the models with a parametric bootstrap in order to explore bootstrap standard errors, using random simulation for 1000 observations.

Fig. 1 presents the multilevel event history model in graphical form. It contains three levels: spatial, country, and the repeated information about various tourism indicators over time. The outcome variable is at the time level: either a recession cycle is observed or the event is censored. At the time level, only one explanatory variable is used: the length of the recession. 
Figure 1: Graphical representation of a multilevel recession event history model

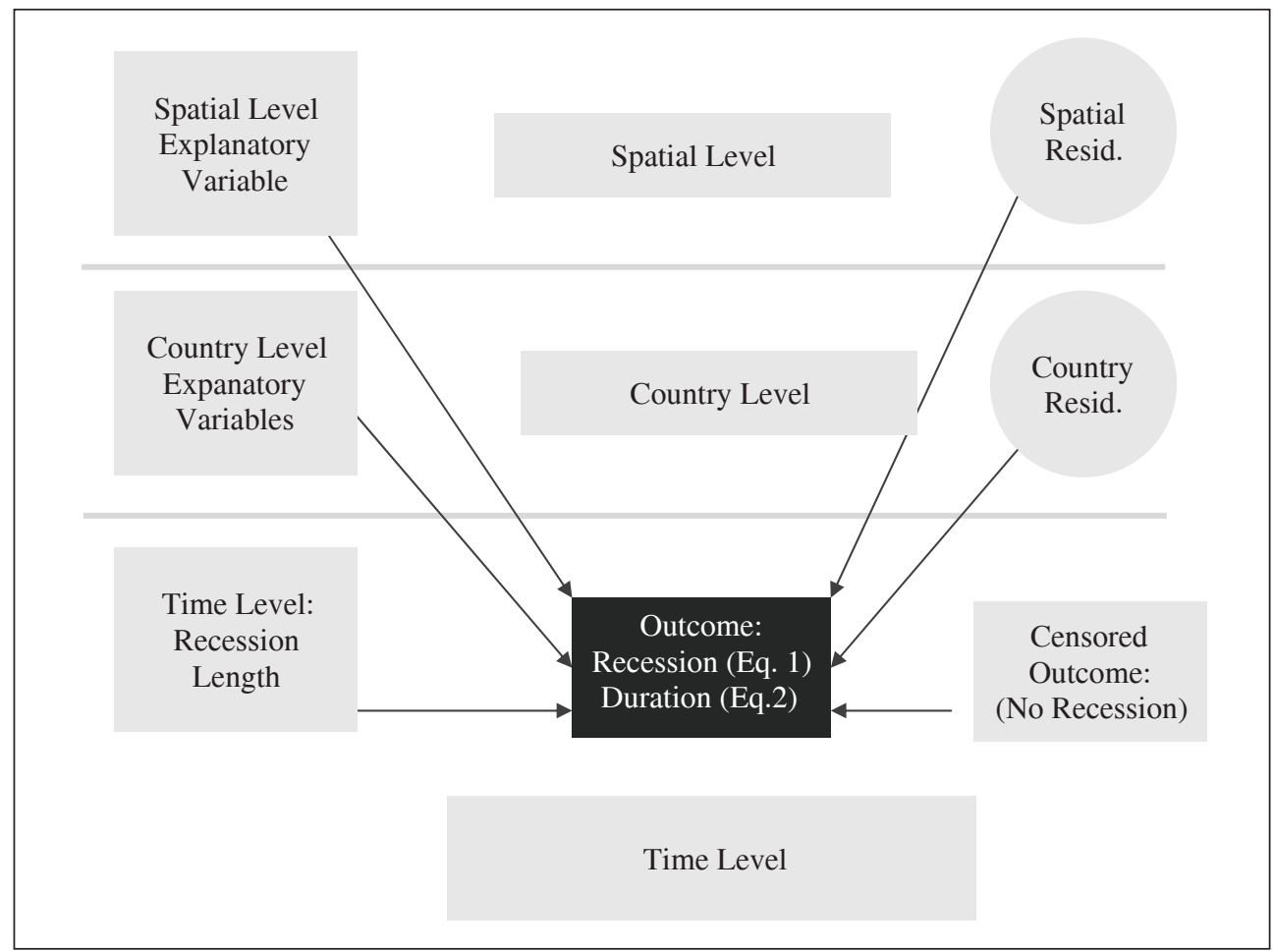

Source: Authors

This explanatory variable is essential because it represents the length of time that the country has been "at risk" in a recession. There are also explanatory variables at the country level and the geolocation level, which were listed earlier in this chapter. Note that Fig.1 includes two residual error terms: one at the country level and one at the spatial level. It is this more complicated error structure that makes the use of multilevel modelling necessary.

\section{Empirical data and analysis}

\subsection{The data}

In this study, the model for multilevel data is estimated for a sample of 71 countries (of which most had data for the years 2006 to 2013 fully available from the article, "Timeline of the Great Recession" (World Heritage Encyclopaedia).

In this section, we give a brief overview of the Great Recession. Our dataset displays all national recessions appearing in the period 2006 to 2013 (for the 71 countries with 
available data), according to the common recession definition: that a recession has occurred whenever the seasonally adjusted real GDP contracts quarter over quarter, for a minimum of two consecutive quarters (six months). The countries used in the analysis are based on a wide spectrum of European countries plus others which are scattered around the world (Albania, Argentina, Australia, Austria, Belgium, Belize, Bolivia, Brazil, Bulgaria, Canada, Chile, China, Colombia, Costa Rica, Croatia, Cyprus, Czech Republic, Denmark, Ecuador, El Salvador, Estonia, Finland, France, Germany, Greece, Hong Kong, Hungary, Iceland, India, Indonesia, Ireland, Israel, Italy, Jamaica, Japan, Kazakhstan, Latvia, Lithuania, Luxembourg, Macedonia, Malaysia, Malta, Mexico, Moldova, Netherlands, New Zealand, Norway, Paraguay, Peru, Philippines, Poland, Portugal, Romania, Russia, Serbia, Singapore, Slovakia, Slovenia, South Africa, South Korea, Spain, Sweden, Switzerland, Taiwan, Thailand, Turkey, Ukraine, United Kingdom, United States, Uruguay and Venezuela).

A smaller group of countries avoided a wave of recession in the same period. Namely only 11 out of the 71 listed countries (Poland, Slovakia, Moldova, India, China, South Korea, Indonesia, Australia, Uruguay, Colombia and Bolivia).

The number of countries in recession, gradually as time elapsed toward 2010, followed a form of inverted-U curve pattern.

Only two countries (Iceland and Jamaica) were in recession in Q4-2007, and this because the few recessions appearing early in 2006-07 seemed to be disjointed events caused by other factors and were never associated as being part of the Great Recession and its power of spillovers around the world. One year before the peak, in Q1-2008, only six countries were in recession (Iceland, Sweden, Finland, Ireland, Portugal and New Zealand). In the subsequent time period in Q2-2008, the number of countries in recession increased to 25, soon after to 39 in Q3-2008 and then to as many as 53 in Q4-2008. At the steepest part of the Great Recession in Q1-2009 (darkest quarter), a total of 59 out of 71 countries, or $83 \%$ were simultaneously in recession.

After that, the number of countries in recession noted a rapidly decreasing trend; 37 countries in Q2-2009, 13 in Q3-2009 and 11 in Q4-2009. One year after the peak of the recession, in Q1-2010, only seven countries were in recession (Greece, Croatia, Romania, Iceland, Jamaica, Venezuela and Belize).

Subsequent follow-up recessions in 2010-2013 were limited to Belize, El Salvador, Paraguay, Jamaica, Japan, Taiwan, New Zealand and 24 out of 50 European countries (including Greece, Croatia and other countries). As of October 2014 (that year is outside the scope of our analysis and did not enter in our dataset), only five out of the 71 countries with available quarterly data (Cyprus, Italy, Croatia, Belize and El Salvador) were still in ongoing recession; and generally all these countries are considered tourism destinations. 
The definition of variables sourced from Worldlibrary.org used in the analysis is as follows: RECESS is a binary variable equal to one if a recession prevails at time interval $\mathrm{t}$ and zero otherwise; MONTH is a recession/expansion period(s) during 2006-2013 (measured by quarter-on-quarter changes of seasonally adjusted real GDP, as per the latest revised Q3-2013 data from 10 January 2014) expressed in number of months; RIGHT_CENS is a binary variable equal to one if a recession is observed at the end of the observation and zero otherwise; EMPL_PERC is the direct contribution of travel and tourism to employment and is defined as a percentage of the overall economy employment and is sourced from various Country reports of the World Travel \& Tourism Council. The next variables are sourced from the World Bank. SATUR_PC is defined as the ratio between the number of overnight stays and the resident population; ITR_XP is the total international tourism receipts as a percentage of total exports; TS_CSE is travel services as a percentage of commercial service exports; COAS_LAND is the coast to land border ratio as an indication of tourism attractiveness; AIR_PC is air transport, indicated by passengers carried divided into the population; SPATIAL is a binary variable equal to one if a European country and zero otherwise.

\subsection{Descriptive statistics}

Table 1 provides a summary of all data used in the analysis. On average, a recession event in this sample has a duration of 8.8 months $(\mathrm{SD}=9.27)$; in contrast, periods without recessions are on average about three times longer. However, the duration of a recession varies widely between countries, as well as in aggregates (see Tables 2 and 3). The highest range of recession is observed in Greece (Europe) and Argentina (Non-Europe), with similar high levels of duration in the other European countries, some of them with strong tourism participation in aggregate production (Croatia, Ireland, Italy, Portugal, Slovenia, and Spain). The highest level of tourism saturation or tourism employment as a percentage in the overall economy employment was reported in Malta with comparably low rates in Moldova. The levels of the total international tourism receipts as a percentage of total exports varied, with Albania, Belize, Croatia and Jamaica, presenting the most extreme cases. For example, in Venezuela only 1 per cent of exports come from tourism activity. 
Table 1: Descriptive statistics

\begin{tabular}{|c|c|c|c|c|c|}
\hline Variable & Min. & Max. & Range & Mean & Std. dev. \\
\hline RECESS & 0 & 1 & 1 & 0.4 & 0.49 \\
\hline MONTH (recession) & 2 & $\begin{array}{r}69 \\
\text { (Greece, } \\
\text { Argentina) } \\
\end{array}$ & 67 & 8.8 & 9.27 \\
\hline MONTH (no recession) & 0 & 54 & 54 & 23.7 & 16.3 \\
\hline RIGHT_CENS & 0 & 1 & 1 & 0.03 & 0.18 \\
\hline EMPL_PERC & $\begin{array}{r}0.7 \\
\text { (Moldova) }\end{array}$ & $\begin{array}{r}15 \\
\text { (Malta) }\end{array}$ & 14.3 & 4.49 & 3.03 \\
\hline SATUR_PC & $\begin{array}{r}0 \\
\text { (Moldova) }\end{array}$ & $\begin{array}{r}3.40 \\
\text { (Malta) } \\
\end{array}$ & 3.40 & 0.78 & 0.70 \\
\hline ITR_XP & $\begin{array}{r}1 \\
\text { (Venezuela) }\end{array}$ & $\begin{array}{r}65.79 \\
\text { (Albania) }\end{array}$ & 65.79 & 12.19 & 13.35 \\
\hline TS_CSE & $\begin{array}{r}6.7 \\
\text { (Luxemburg) } \\
\end{array}$ & $\begin{array}{r}125.8 \\
\text { (Iceland) } \\
\end{array}$ & 119.1 & 36.70 & 25.52 \\
\hline COAS_LAND & 1 & $\begin{array}{r}47 \\
\text { (Singapore) }\end{array}$ & 46 & 36.7 & 16.7 \\
\hline AIRT_PC & $\begin{array}{r}0 \\
\text { (Macedonia) } \\
\end{array}$ & $\begin{array}{r}15.47 \\
\text { (Ireland) } \\
\end{array}$ & 15.47 & 1.14 & 2.23 \\
\hline EU_NEU & 0 & 1 & 1 & 0.63 & 0.483 \\
\hline
\end{tabular}

Source: Authors' calculation

The scope of travel services as a percentage of commercial service exports was at the highest level overall in Iceland (a country with a strong recession in the recent past), and the lowest level in rich, but tiny Luxemburg. In addition, considering air travel, the relative number of passengers carried by air was highest in Ireland.

The recession occurrence is explored in relation to the size of each explanatory variable considered by box plots (see Appendices, Figures A1-A7). Among them, Figure A2 can be distinguished; it shows that the length of the box plots, if recession occurs, is quite large, justifying our choice of concentrating on the examination of the interference of tourism saturation on recession hazard. Visual inspection of other figures with the rest of the explanatory variables gives an impression of a weak relationship between recession and the imputed variables.

\subsection{Econometric analysis}

The main research objective of this paper was to measure the impact of tourism development on the probability of recession frequency (and risk in terms of duration and severity). The following econometric approach has been applied:

- cross-tabulation of economic cycle variable against spatial country allocation

- logistic regression within a multilevel setting, 
- multilevel GLMM with a Poisson distribution,

- parameter estimation,

- testing the parameters,

- regression diagnostics.

Our prediction that a tourism destination would more easily decline into recession can be tested by a simple cross-tabulation of economic cycle variables against spatial country allocation. More specifically, we try to find some implication that permits a relatively straightforward confrontation between our theory and evidence using prior regression.

Before we can start the multilevel analyses of the importance of the geolocation peculiarity for the recession risks of a country, we must compare the relationship between the recession risk of a country and the percentages of European/NonEuropean countries that have become depressed.

Table 2: Relationship between the recession risk of European and non-European countries, 2007-2013

\begin{tabular}{|l|r|r|r|}
\hline \multirow{2}{*}{$\begin{array}{r}\text { Recession } \\
\text { Risk } \\
\text { cycles }\end{array}$} & $\begin{array}{c}|c| \\
\text { Non-European } \\
\text { countries }\end{array}$ & $\begin{array}{l}\text { Countries } \\
\text { European } \\
\text { countries }\end{array}$ & $\begin{array}{r}\text { Total N } \\
(=100 \%)\end{array}$ \\
\hline Expansion & $66(41 \%)$ & $96(59 \%)$ & 162 \\
\hline Recession & $38(35 \%)$ & $72(65 \%)$ & 110 \\
\hline Expansion \& Recession & $104(38 \%)$ & $168(62 \%)$ & 272 \\
\hline
\end{tabular}

Note: $\chi 2=7.13$, d.f. $=2$, $p$-value $=0.035$

Source: Authors' calculation

Table 2 shows that such an asymmetric relationship does, indeed, exist. The higher the percentage of recession episodes (up to 65\%) applied to European countries rather than non-European countries, although countries that belong to that aggregate are slightly more representative in our dataset. The count ratio for European to nonEuropean countries is 40:31. European countries were more likely to have gone through heavy recession measured by duration; the non-European countries were in far better positions. If we compare the boom-bust cycle in European and non-European countries in 2007-2013, two clear moments emerge and should be discussed. First, we find the European boom-bust episode is much more volatile, as calculated from an international sample. In other words, the European experience has been much more volatile than an average boom-bust pattern. Second, the bust and the recovery pattern in Europe differ markedly from the international pattern of the boom phase. The bust is considerably deeper and recovery comes more often, in longer durations. 
The further question in the analysis was whether the proportions of recession and expansions in the two spatial aggregates are the same. The result is $\chi 2=7.26$, d.f. $=2$, $\mathrm{p}$-value $=0.027$. This indicates that we can reject the null hypothesis; the cycles have significantly different proportions in the two observed groups of countries.

The size distribution of the recession/expansion phenomenon, in relation to the number of months, is given in Table 3.

Table 3: Number of recessions and expansions among spatial aggregates and countries, 2007-2013

\begin{tabular}{|c|c|c|}
\hline $\begin{array}{l}\text { The severity } \\
\text { of the recession }\end{array}$ & $\begin{array}{c}\text { Recession } \\
\text { (total countries) }\end{array}$ & $\begin{array}{c}\text { Expansion } \\
\text { (total countries) }\end{array}$ \\
\hline $\mathrm{M}<20$ & 102 & 65 \\
\hline $21<\mathrm{M}<45$ & 6 & 71 \\
\hline $46<\mathrm{M}<69$ & 2 & 26 \\
\hline Times & 110 & 162 \\
\hline & $\begin{array}{l}\text { Recession } \\
\text { (European) }\end{array}$ & $\begin{array}{l}\text { Expansion } \\
\text { (European) }\end{array}$ \\
\hline $\mathrm{M}<20$ & $\begin{array}{l}63 \text { (Albania, Austria, Belgium, Bulgaria, } \\
\text { Cyprus, Czech Republic, Denmark, } \\
\text { Estonia, Finland, France, Germany, } \\
\text { Hungary, Iceland, Latvia, Lithuania, } \\
\text { Luxembourg, Macedonia, Malta, } \\
\text { Netherlands, Norway, Romania, Russia, } \\
\text { Serbia, Sweden, Switzerland, Ukraine, } \\
\text { UK, Turkey, etc.) }\end{array}$ & 38 \\
\hline $21<\mathrm{M}<45$ & $\begin{array}{l}6 \text { (Croatia, Ireland, Italy, Portugal, } \\
\text { Slovenia, Spain) }\end{array}$ & 47 \\
\hline $46<M<69$ & 1 (Greece) & 10 \\
\hline Times & 70 & 95 \\
\hline & $\begin{array}{c}\text { Recession } \\
\text { (Non-European) }\end{array}$ & $\begin{array}{c}\text { Expansion } \\
\text { (Non-European) }\end{array}$ \\
\hline $\mathrm{M}<20$ & $\begin{array}{l}39 \text { (Belize, Brazil, Canada, Chile, Costa } \\
\text { Rica, Ecuador, El Salvador, Hong Kong, } \\
\text { Jamaica, Japan, Kazakhstan, Malaysia, } \\
\text { Mexico, New Zealand, Paraguay, Peru, } \\
\text { Philippines, Singapore, South Africa, } \\
\text { Thailand, US, Venezuela, etc.) }\end{array}$ & 27 \\
\hline $21<\mathrm{M}<45$ & 0 & 24 \\
\hline $46<M<69$ & 1 (Argentina) & 16 \\
\hline Times & 40 & 67 \\
\hline
\end{tabular}

Note: $\mathrm{M}=$ number of months; Times= number of events

Source: Authors' calculation 
Having cycle-time interval-country data, we have to check for the month of recession in all countries (Table 3). The parameter of this variable has the usual direction: the longer a full cycle (the recession plus expansion phase) exists, the higher the risk of recession.

Recession risks with short durations are especially high: most terminated within the first year and half of existence. However, six of the recessions in European countries were longer than three and a half years (Croatia, Ireland, Italy, Portugal, Slovenia, and Spain), and did not match the rest of the world. The countries with prolonged recessions were Greece and Argentina. Some of the countries where deep recessions hit are tourism destinations.

The next two tables (Table 4 and 5) show the regression result.

Table 4: Recession risks of countries explained by tourism indicator, and individual and spatial characteristics (logistic regression on recession-month-country data within multi-levels)

\begin{tabular}{|c|c|c|c|c|c|c|c|c|c|}
\hline \multirow{2}{*}{\begin{tabular}{|c|} 
Dependent \\
variable \\
(binary variable \\
$1 / 0)$ \\
\end{tabular}} & \multicolumn{9}{|c|}{ Model } \\
\hline & Null & 1 & 2 & 3 & 4 & 5 & 6 & 7 & 8 \\
\hline Intercept & $\begin{array}{r}-0.387^{* * *} \\
(0.123)\end{array}$ & $\begin{array}{c}0.964 \\
(0.322)^{* *}\end{array}$ & $\begin{array}{r}0.872 \\
(0.329)^{* *}\end{array}$ & $\begin{array}{r}0.885 \\
(0.329)^{* * *}\end{array}$ & $\begin{array}{r}0.897 \\
(0.363)^{*}\end{array}$ & $\begin{array}{r}0.881 \\
(0.363)^{*}\end{array}$ & $\begin{array}{r}0.517 \\
(0.430)\end{array}$ & $\begin{array}{r}0.505 \\
(0.458)\end{array}$ & $\begin{array}{r}0.505 \\
(0.458) \\
\end{array}$ \\
\hline \multicolumn{10}{|c|}{ Time-month level } \\
\hline $\begin{array}{l}\text { Length of } \\
\text { recession } \\
\text { (time varying) }\end{array}$ & & $\begin{array}{r}-0.099 \\
(0.015)^{* * * *}\end{array}$ & $(0.015)^{-0.102}$ & $(0.015)^{-0.103}$ & $(0.015)^{* * * *}$ & $(0.016)^{* * * *}$ & $\begin{array}{r}-0.107 \\
(0.016)^{* * *}\end{array}$ & $(0.016)^{-0.107}$ & $\begin{array}{r}-0.107 \\
(0.016)^{* * *}\end{array}$ \\
\hline \multicolumn{10}{|c|}{ Country level } \\
\hline EMPL_PERC & & \begin{tabular}{r|}
0.018 \\
$(0.046)$ \\
\end{tabular} & \begin{tabular}{r|}
-0.002 \\
$(0.049)$ \\
\end{tabular} & $\begin{array}{r}0.030 \\
(0.062) \\
\end{array}$ & $\begin{array}{r}0.031 \\
(0.064) \\
\end{array}$ & $\begin{array}{r}0.032 \\
(0.064) \\
\end{array}$ & $\begin{array}{r}0.040 \\
(0.064) \\
\end{array}$ & $\begin{array}{r}0.040 \\
(0.064) \\
\end{array}$ & $\begin{array}{r}0.040 \\
(0.064) \\
\end{array}$ \\
\hline SATUR_PC & & & $\begin{array}{c}0.272^{*} \\
(0.212)\end{array}$ & $\begin{array}{c}0.289^{*} \\
(0.125)\end{array}$ & $\begin{array}{c}0.301^{*} \\
(0.148)\end{array}$ & $\begin{array}{c}0.276^{*} \\
(0.123)\end{array}$ & $\begin{array}{c}0.241^{*} \\
(0.117)\end{array}$ & $\begin{array}{c}0.238^{*} \\
(0.150)\end{array}$ & $\begin{array}{r}0.138 \\
(0.250)\end{array}$ \\
\hline ITR_XP & & & & $\begin{array}{r}-0.011 \\
(0.013)\end{array}$ & $\begin{array}{r}-0.010 \\
(0.015)\end{array}$ & $\begin{array}{r}-0.009 \\
(0.015)\end{array}$ & $\begin{array}{r}0.052 \\
(0.042)\end{array}$ & $\begin{array}{r}0.052 \\
(0.042)\end{array}$ & $\begin{array}{r}0.052 \\
(0.042)\end{array}$ \\
\hline TS_CSE & & & & & $\begin{array}{r}0.001 \\
(0.009) \\
\end{array}$ & $\begin{array}{c}0.032^{*} \\
(0.009) \\
\end{array}$ & $\begin{array}{l}0.062 * \\
(0.025) \\
\end{array}$ & $\begin{array}{r}0.052^{*} \\
(0.021) \\
\end{array}$ & $\begin{array}{c}0.018^{*} \\
(0.007) \\
\end{array}$ \\
\hline AIR_PC & & & & & & $\begin{array}{r}0.064 \\
(0.079) \\
\end{array}$ & $\begin{array}{r}0.077 \\
(0.080) \\
\end{array}$ & $\begin{array}{r}0.076 \\
(0.082) \\
\end{array}$ & $\begin{array}{r}0.076 \\
(0.082) \\
\end{array}$ \\
\hline $\begin{array}{l}\text { ITR_XP*TS } \\
\text { CSE }\end{array}$ & & & & & & & $\begin{array}{r}-0.001 \\
(0.001) \\
\end{array}$ & $\begin{array}{r}-0.107 \\
(0.016)^{* * * *} \\
\end{array}$ & $\begin{array}{r}0.001 \\
(0.009) \\
\end{array}$ \\
\hline $\begin{array}{l}\text { COAST_ } \\
\text { LAND }\end{array}$ & & & & & & & & $\begin{array}{r}0.001 \\
(0.009) \\
\end{array}$ & $\begin{array}{r}-0.001 \\
(0.001) \\
\end{array}$ \\
\hline \multicolumn{10}{|c|}{ Spatial level } \\
\hline $\begin{array}{l}\text { Reference: } \\
\text { European } \\
\text { country }\end{array}$ & & & & & & & & & $\begin{array}{r}0.326 \\
(0.381)\end{array}$ \\
\hline
\end{tabular}




\begin{tabular}{|c|c|c|c|c|c|c|c|c|c|}
\hline \multirow{2}{*}{\begin{tabular}{|c} 
Dependent \\
variable \\
(binary variable \\
$1 / 0$ )
\end{tabular}} & \multicolumn{9}{|c|}{ Model } \\
\hline & Null & 1 & 2 & 3 & 4 & 5 & 6 & 7 & 8 \\
\hline \multicolumn{10}{|c|}{ Covariance Parameters } \\
\hline $\begin{array}{l}\text { Residual } \\
\text { (country level } \\
\text { variance) }\end{array}$ & $\begin{array}{r}0.318 \\
(0.564)\end{array}$ & & $\begin{array}{r}0.234 \\
(0.483)\end{array}$ & $\begin{array}{r}0.235 \\
(0.485)\end{array}$ & $\begin{array}{r}0.235 \\
(0.485)\end{array}$ & $\begin{array}{r}0.236 \\
(0.486)\end{array}$ & $\begin{array}{r}0.236 \\
(0.486)\end{array}$ & $\begin{array}{r}0.236 \\
(0.486)\end{array}$ & $\begin{array}{r}0.239 \\
(0.489)\end{array}$ \\
\hline $\begin{array}{l}\text { Intercept } \\
\text { (country level } \\
\text { variance) }\end{array}$ & $\begin{array}{r}0.000 \\
(0.000)\end{array}$ & & $\begin{array}{r}0.000 \\
(0.000)\end{array}$ & $\begin{array}{r}0.000 \\
(0.000)\end{array}$ & $\begin{array}{r}0.000 \\
(0.000)\end{array}$ & $\begin{array}{r}0.000 \\
(0.000)\end{array}$ & $\begin{array}{r}0.000 \\
(0.000)\end{array}$ & $\begin{array}{r}0.000 \\
(0.000)\end{array}$ & $\begin{array}{r}0.000 \\
(0.000)\end{array}$ \\
\hline $\begin{array}{l}\text { Intercept } \\
\text { (spatial level } \\
\text { variance) }\end{array}$ & & & & & & & & & $\begin{array}{r}0.000 \\
(0.000)\end{array}$ \\
\hline \multicolumn{10}{|c|}{ Model Fit Parameters } \\
\hline AIC & 371.1 & 299.026 & 299.505 & 300.776 & 302.770 & 304.129 & 304.436 & 306.431 & 308.431 \\
\hline $\mathrm{BIC}$ & 378.3 & 313.449 & 317.534 & 322.411 & 328.011 & 332.975 & 336.889 & 342.489 & 348.095 \\
\hline $\begin{array}{l}\text { Deviance } \\
(-2 L L)\end{array}$ & 367.1 & & 290.9 & 289.2 & 288.6 & 288.7 & 287.4 & 288.1 & 287.4 \\
\hline $\begin{array}{l}2(\mathrm{df}) \\
\text { (comparison } \\
\text { with previous } \\
\text { model) }\end{array}$ & & & $76.193^{* * *}$ & 1.651 & 0.493 & 0.005 & 0.0025 & 0.616 & 0.745 \\
\hline
\end{tabular}

Notes: Null model $=$ Intercept; Model $1=$ Null model + time-level; Model $2=$ Model $1+$ individual-level tourism intensity control variable; Model $3=$ Model $2+$ individuallevel tourism intensity control variables; Model $4=$ Model $3+$ individual-level tourism intensity control variables; Model $5=$ Model $4+$ individual-level tourism intensity control variables + interaction term; Model $6=$ Model $5+$ individual-level tourism intensity control variables; Model $7=$ Model $6+$ individual-level tourism intensity control variables; Model $8=$ Model $7+$ individual-level tourism intensity control variables + spatial level control variable. Bootstrap standard errors are in parentheses; values in bold are significant at 0.05 level $(*) ; 0.001$ level $(* *)$; and 0.0001 level $(* * *)$.

Source: Authors' calculation

Table 4 presents the regression coefficients and associated standard errors for several consecutive models linked to logistic regression when the outcome is either a recession or not a recession event, according to Equation 2. The multilevel analysis tested eight different models (Table 4).

Unless otherwise indicated, all bolded effects (in both Tables) are significant at least at the 0.05 level. In Model 1, only the time level variables of interest were introduced (number of months). In this section, we mention only opposing evidence regarding the coefficient estimation. The tourism receipts per se as a percentage of total exports are surprisingly related to neither recession risk nor recession duration. 
Zdravko Šergo, Jasmina Gržinić, Mirela Sučić Čevra • The tourism and travel industry...

Table 5: Duration risks of recession by country explained by tourism indicator, and individual and spatial characteristics (Multilevel GLMM with a Poisson distribution)

\begin{tabular}{|c|c|c|c|c|c|c|c|c|}
\hline $\begin{array}{l}\text { Dependent variable } \\
\text { (binary variable }\end{array}$ & \multicolumn{8}{|c|}{ Model } \\
\hline & Null & 1 & 2 & 3 & 4 & 5 & 6 & 7 \\
\hline Intercept & $\begin{array}{r}-0.933 \\
(0.440)^{*}\end{array}$ & $\begin{array}{r}-1.420 \\
(0.613)^{*} \\
\end{array}$ & $\begin{array}{r}-1.506 \\
(0.661)^{*}\end{array}$ & $\begin{array}{r}-1.441 \\
(0.684)^{*} \\
\end{array}$ & $\begin{array}{r}-1.442 \\
(0.684)^{*}\end{array}$ & $\begin{array}{r}-1.633 \\
(0.778)^{*} \\
\end{array}$ & $\begin{array}{r}-1.505 \\
(0.728)^{*} \\
\end{array}$ & $\begin{array}{r}-1.505 \\
(0.728)^{*} \\
\end{array}$ \\
\hline obs_effect & $\begin{array}{r}-0.001 \\
(0.002)\end{array}$ & $\begin{array}{r}0.000 \\
(0.003)\end{array}$ & $\begin{array}{r}0.000 \\
(0.003)\end{array}$ & $\begin{array}{r}0.000 \\
(0.003)\end{array}$ & $\begin{array}{r}0.000 \\
(0.003)\end{array}$ & $\begin{array}{r}0.000 \\
(0.003)\end{array}$ & $\begin{array}{r}0.000 \\
(0.003)\end{array}$ & $\begin{array}{r}0.000 \\
(0.003) \\
\end{array}$ \\
\hline \multicolumn{9}{|c|}{ Country level } \\
\hline EMPL_PERC & & $\begin{array}{r}0.079 \\
(0.066) \\
\end{array}$ & $\begin{array}{r}0.078 \\
(0.084) \\
\end{array}$ & $\begin{array}{r}0.085 \\
(0.086) \\
\end{array}$ & $\begin{array}{r}0.086 \\
(0.086) \\
\end{array}$ & $\begin{array}{r}0.088 \\
(0.086) \\
\end{array}$ & $\begin{array}{r}0.084 \\
(0.083) \\
\end{array}$ & $\begin{array}{r}0.084 \\
(0.083) \\
\end{array}$ \\
\hline SATUR_PC & & & $\begin{array}{c}0.357 * \\
(0.169)\end{array}$ & $\begin{array}{c}0.385 * \\
(0.172)\end{array}$ & $\begin{array}{c}0.393 * \\
(0.158) \\
\end{array}$ & $\begin{array}{c}0.337 * \\
(0.152)\end{array}$ & $\begin{array}{c}0.369 * \\
(0.138)\end{array}$ & $\begin{array}{r}0.166 \\
(0.333) \\
\end{array}$ \\
\hline ITR_XP & & & & $\begin{array}{r}0.000 \\
(0.022) \\
\end{array}$ & $\begin{array}{r}0.001 \\
(0.022) \\
\end{array}$ & $\begin{array}{r}0.033 \\
(0.066) \\
\end{array}$ & $\begin{array}{r}0.035 \\
(0.063) \\
\end{array}$ & $\begin{array}{r}0.035 \\
(0.063) \\
\end{array}$ \\
\hline TS_CSE & & & & & $\begin{array}{r}-0.004 \\
(0.011) \\
\end{array}$ & $\begin{array}{r}0.031 * \\
(0.014) \\
\end{array}$ & $\begin{array}{r}0.001 \\
(0.013) \\
\end{array}$ & $\begin{array}{r}0.001 \\
(0.013) \\
\end{array}$ \\
\hline AIR_PC & & & & & & $\begin{array}{r}0.033 \\
(0.098) \\
\end{array}$ & $\begin{array}{r}0.065 \\
(0.095) \\
\end{array}$ & $\begin{array}{r}0.065 \\
(0.095) \\
\end{array}$ \\
\hline ITR_XP*TS_CSE & & & & & & & $\begin{array}{r}-0.004 \\
(0.013) \\
\end{array}$ & $\begin{array}{r}-0.001 \\
(0.001) \\
\end{array}$ \\
\hline COAST_LAND & & & & & & & $\begin{array}{r}-0.001 \\
(0.001)\end{array}$ & $\begin{array}{r}-0.004 \\
(0.013) \\
\end{array}$ \\
\hline \multicolumn{9}{|c|}{ Spatial level } \\
\hline $\begin{array}{l}\text { Reference: European } \\
\text { country }\end{array}$ & & & & & & & & $\begin{array}{r}0.002 \\
(0.015) \\
\end{array}$ \\
\hline \multicolumn{9}{|c|}{ Covariance Parameters } \\
\hline $\begin{array}{l}\text { Residual (observation } \\
\text { effect level variance) }\end{array}$ & $\begin{array}{c}7.077^{*} \\
(2.615) \\
\end{array}$ & $\begin{array}{c}7.060^{*} \\
(2.657) \\
\end{array}$ & $\begin{array}{r}7.021 \\
(2.118) \\
\end{array}$ & $\begin{array}{r}7.017 \\
(2.516) \\
\end{array}$ & $\begin{array}{r}7.013 \\
(2.516) \\
\end{array}$ & $\begin{array}{r}6.958 \\
(2.480) \\
\end{array}$ & $\begin{array}{r}6.522 \\
(2.520) \\
\end{array}$ & $\begin{array}{r}6.522 \\
(2.496) \\
\end{array}$ \\
\hline $\begin{array}{l}\text { Intercept (country level } \\
\text { variance) }\end{array}$ & $\begin{array}{r}0.000 \\
(0.000) \\
\end{array}$ & $\begin{array}{r}0.000 \\
(0.000) \\
\end{array}$ & $\begin{array}{r}0.000 \\
(0.000) \\
\end{array}$ & $\begin{array}{r}0.000 \\
(0.000) \\
\end{array}$ & $\begin{array}{r}0.000 \\
(0.000) \\
\end{array}$ & $\begin{array}{r}0.001 \\
(0.038) \\
\end{array}$ & $\begin{array}{r}0.0003 \\
(0.0185) \\
\end{array}$ & $\begin{array}{r}0.000 \\
(0.005) \\
\end{array}$ \\
\hline $\begin{array}{l}\text { Intercept (spatial level } \\
\text { variance) }\end{array}$ & & & & & & & & $\begin{array}{r}0.000 \\
(0.000) \\
\end{array}$ \\
\hline \multicolumn{9}{|c|}{ Model Fit Parameters } \\
\hline AIC & 1146.233 & 1150.767 & 1150.440 & 1152.321 & 1154.247 & 1155.964 & 1158.289 & 1158.289 \\
\hline $\mathrm{BIC}$ & 1160.656 & 1176.008 & 1175.681 & 1181.167 & 1186.700 & 1192.022 & 1197.953 & 1197.953 \\
\hline Deviance (-2LL) & 1136.5 & & 1085.7 & 1083.7 & 1085.6 & 1081 & 1083.8 & 1082.3 \\
\hline $\begin{array}{l}\chi 2(\mathrm{df}) \text { (comparison with } \\
\text { previous model) }\end{array}$ & & & 1.525 & 0.472 & 0.003 & 0.0015 & 0.513 & 0.546 \\
\hline
\end{tabular}

Notes: Ibidem

Source: Authors' calculation

This finding contradicts our theory that recession risks are strongly related to a predominance of tourism in the economic structure and attitudes toward an export earning policy. Next, the impact of direct employment in the tourism sector on the recession occurrence is mainly positive but insignificant. Being a country with a 
long coastline does not increase the recession risk significantly compared with the risk for a less maritime country. Indeed, that effect, in Model 8 (Table 4), runs against the expectation: having a wider extent of shoreline decreases the recession risk of a country, although insignificantly. Contrary to what might be expected, a country having more air passengers per capita, with the majority of them tourists, has no statistically significant positive effect on the recession risks of an economy.

The relationship between recession severity response variables (recession duration in months), and the tourism predictors (Equation 3) was weaker than that for recession duration frequency (Table 5).

Turning to the explanatory significance of the models, it should be noted in advance that assessing absolute model fits and explanatory powers in multilevel models is much more complicated than in single-level regressions, since the commonly used R-square statistic cannot be applied directly because variance in the dependent variable can originate from variance between level-one units (individual country) as also from variance between level-two units (geolocation) (For a detailed discussion, see Hox et al., 2010). We have not done this part of the reliability diagnostics of the models because only the last Model(s) checks for spatial level variables. However, further model fits for comparing the different models like deviance and Akaike's Information Criterion (AIC) can be derived from Tables 4 and 5. These criteria should not be interpreted absolutely, but only for the purpose of selecting the model that fits best by searching for the lowest values. As can be seen, independent of the criterion used, each model after Model 2 is not able to improve the data fit.

\section{Results and discussion}

The main aim of this paper was to study whether tourism intensity during the Great Recession impacted risks in regard to national economies slowing down, economic robustness diminishing and countries entering into recessions. In the theoretical part of this paper, we formed the conjecture that recession episodes are heavier and more prolonged in countries that are international tourism destinations.

Recent empirical literature did not provide great help. Outlining similarities with other authors' models to compare our results in regard to economic significance with them is quite impossible. In the general panorama of past-to-present literature about tourism and recession relationships, early on, we did not find similar research. Thus, using the opinions and results of others, in an economic sense, to justify the efforts of this research are absent from the discussion.

The effects of the number of months (duration) of recessions were significant and in the assumed direction; the number of prolonged recessions persistently decreased with the number of recessions in an individual country. Model 2 took into account 
the country control variables, i.e. tourism saturation as a first tourism indicator. As foreseen in the conceptual chapter, saturation with tourist arrivals per capita, although slightly below the threshold, is of significant statistical value. Looking at the magnitude and the sign of the estimated coefficient as a basis to measure the economic importance of that variable in our model, we see that the SATUR_PC parameter is substantial in both regressions with the predicted sign. Hence, that coefficient bears strong economic significance. No differences were found in adding additional variables to the effect of tourism saturation on the response variable.

Model 2 shows the positive effect of a country's saturation with tourism flows on the recession risk of its economy. This mirrors prior results, the longer a recession event exists (Table 5), the higher the saturation of the country with tourist arrivals; hence the risks of prolonged recessions are especially high in tourist oriented countries. Thus, we notice that saturation as an index of tourism intensity is economically significant in our model with regard to both regressions.

It reveals that having a higher percentage of travel services in commercial service exports increases significantly the recession risks of a country. Model 5 shows the positive economic effect of having a high share of travel services in service export on the recession risk of the sample countries. The strength of their parameters hardly changes by checking for the other characteristics, and that parameter remains highly significant (Models 6 and 7) in logistic regression. The severity of risk and recession in that kind of individual country is of a long duration (Model 5 in Table 6 that referred to Poisson regression).

This result is of less economic significance due to the lower magnitude of the TS CSE coefficient. However, mutual interactions between tourist receipts and tourist services indicators were tested and, in the recession duration model, a positive link between the interaction term and recession duration is found (Table 5). It reveals that a higher amount of tourist receipts from foreign tourists interlinked with export of travel services is a relevant economic predictor of duration for a recession.

\section{Conclusion}

By researching and writing this paper, an in-depth analysis of the research questions of why some countries are less able to skip deep recessions than others has been conducted as well as the issue of whether intensification in tourism sector development has some impact on this phenomenon. Hypotheses were developed to test these questions. This study has helped to answer the novel question, what leads a country to either fall into or escape the perils of a Great Recession? by showing that tourism intensity at the time level, and especially at the country level, is partially linked to a greater inclination towards recession. 
By analysing data from over 71 countries in 2006-2013, it was shown that, as hypothesised, some of the measured characteristics of their tourism economy could explain recession risk. The main research question of this paper can be answered only partially and not unequivocally positively. The new contribution proceeds from the alternative evidence that there is a similarity in the recession risks of countries as well as the severity of recessions, in a world with a higher saturation of tourists (overnight stays) per capita. Whilst the effects of tourism saturation at the country level supports the proposed hypotheses in a positive and economically relevant way, due to its magnitude, the findings with regard to international tourism receipts in the country did not, because they reduced, rather than increased, the probability of recession and its duration. However, the apparent paradox (which contradicts our theory) that countries that do include tourism earnings as the important export policy instruments, or have a huge number of workers in the tourism sector are gripped less by recessions is untrue, due to lack of statistical significance.

By showing that international tourism receipts and tourism services go hand in hand with longer recession duration, this paper concludes that dominant tourism features seem to be a noteworthy construct to explain differences in inclination towards recession episodes, especially when drawing global cross-country comparisons. Whether the effect of tourism intensity by other indicators is really related to the Great Recession must be considered in future studies. In any case, this paper hopes to enrich the theoretical and empirical encounters of tourism as a phenomenon and the Great Recession as a mega-critical event in the recent economic history, and supposes that tourism should be added to the existing literature of correlation of recessions.

The data from the given data sources have been examined in a consistent manner and very carefully for a given time span. The research limitations and problems of this study refer to the short time horizon applied (limited exclusively to the years of the Great Recession); therefore, we attempted to run different but compatible regression models (logistic regression on recession-month-country data within a multilevel setting and a multilevel GLMM with a Poisson distribution). Because we obtained a consistent story with both models, we recommend introducing new tourism indices in the hope of reaching a satisfactory conclusion.

We foresee relevant policy implications of the results obtained by this research. Primarily, policy makers in overwhelmingly tourism-oriented countries should gradually introduce policies to reduce excess tourism and reduce its position as a dominant sector by optimising the countries' economic structures. 


\section{References}

Alegre, J., Pou, L. (2016), "US household tourism expenditure and the great recession: An analysis with the consumer expenditure survey", Tourism economics, Vol. 22, No. 3, pp. 608-620, doi: 10.5367/te.2014.0429.

Bates, D., et al. (2015) "Fitting Linear Mixed-Effects Models Using 1me4", Journal of Statistical Software, Vol. 67, No. 1, pp. 1-48, doi: 10.18637/jss.v067.i01.

Burnham K.P., Anderson D.R. (2002) Model Selection and Multimodal Inference: A Practical Information-Theoretic Approach, 2nd edn. Springer-Verlag, USA: New York.

Burns, A.F., Mitchell W.C. (1946) Measuring Business Cycles, National Bureau of Economic Research, New York.

Callaghan, N., Tol, R.S.J. (2013) "UK Tourists, the Great Recession and Irish Tourism Policy", The Economic and Social Review, Vol. 44, No. 1, pp. 103-116.

Candela G., Figini, P. (2012) The Economics of Tourism Destinations, SpringerVerlag: Berlin Heidelberg, doi: 10.1007/978-3-642-20874-4_4.

Cellini, R., Cuccia, R. (2015) "The economic resilience of tourism industry in Italy: What the 'Great Recession' Data Show", Tourism Management Perspectives, Vol. 16, pp. 346-356, doi: 10.1016/j.tmp.2015.09.007.

Country Reports, WTTC - World Travel and Tourism Council, https://www.wttc. org/research/economic-research/economic-impact-analysis/country-reports, [Accessed: November 3, 2017].

Eugenio-Martin, J.L., Campos-Soria, J.A. (2014) "Economic crisis and tourism Expenditure cutback decision", Annals of Tourism Research, Vol. 44, pp. 5373, doi: 10.1016/j.annals.2013.08.013.

Friedman, M. (1950) "Wesley C. Mitchell as an Economic Theorist", Journal of Political Economy, Vol. 58, No. 6, pp. 465-493, doi: 10.1086/257011.

Hansen, A.H. (1949) "Wesley Mitchell, Social Scientist and Social Counsellor", The Review of Economics and Statistics, Vol. 31, No. 4, pp. 245-255, doi: $10.2307 / 1928646$.

Homan, P. (1928) Contemporary Economic Thought, New York: Harper.

Hox, J.J., Moerbeek, M., Van de Schoot, R. (2010) Multilevel Analysis: Techniques and Applications, $2^{\text {nd }}$ ed., Routledge, New York, doi: 10.4324/9780203852279.

Koopmans, T.C. (1947) "Measurement Without Theory", The Review of Economic Statistics, Vol. 29, No. 3, pp. 161-172, doi: 10.2307/1928627.

Krugman, P., Venables, A.J. (1995) "Globalization and the inequality of nations", Quarterly Journal of Economics, Vol. 110, No. 4, pp. 857-80, doi: 10.3386/ w5098.

Krugman, P. (1991) "Increasing returns and economic geography", Journal of Political Economy, Vol. 99, pp. 483-99, doi: 10.1086/261763. 
Kuznets, S. (1949) "Wesley Clair Mitchell, 1874-1948: An Appreciation”, Journal of the American Statistical Association, Vol. 44, pp. 126-131, doi: $10.2307 / 2280356$.

Kydland, F., Prescott, E. (1990) "Business Cycles: Real Facts and a Monetary Myth", Quarterly Review, Federal Reserve Bank of Minneapolis, Vol. 14, No. 2, pp. 3-18, doi: 10.4324/9780203070710.pt6.

Lindert, P.H. (1981) Comments on "Understanding 1929-1933" In Bruner, C. (ed) The Great Depression revisited., 3rd edition, Kluwer. Nijhoff Publishing. Boston/The Hague/London, 5-48, doi: 10.1007/978-94-009-8135-5_5.

Lucas, R. (1980) "Methods and Problems in Business Cycle Theory", Journal of Money, Credit and Banking, Part 2, Vol. 12, No. 4, pp. 696-715, doi: 10.2307/1992030.

Mauldin, J., Tepper, J. (2011) Endgame: The End of the Debt Supercycle and How It Changes Everything, 1st ed. John Wiley \& Sons.

McConnell, M.M., Perez-Quiros, G. (2000) "Output Fluctuations in the United States: What Has Changed since the Early 1980's?", American Economic Review, Vol. 90, No. 5, pp. 1464-1476, doi: 10.1257/aer.90.5.1464.

Mills, F.C. (1949) "Memorials: Wesley Clair Mitchell, 1874-1948". The American Economic Review, Vol. 39, No. 3, pp. 730-742.

Mitchell, W.C. (1927) Business Cycles and Its Setting, New York: NBER.

Murgoci, C.S. et al. (2009), "Global recession and its effect on tourism and travel industry", Annals of DAAAM \& Proceedings, January, https://www.highbeam. com/doc/1G1-224712978.html [Accessed: January 14, 2016].

Perles-Ribes, J.F., et al. (2013), "Economic crisis and tourism competitiveness in Spain: permanent effects or transitory shocks?", Current Issues in Tourism, Vol. 19, No. 12, pp. 1210-1234, doi: 10.1080/13683500.2013.849666.

Poudyal, N.C. et al. (2013) "A time series analysis of the Impact of recession on national park visitation in the United States", Tourism Management, Vol. 35, pp. 181-189, doi: 10.1016/j.tourman.2012.07.001.

Prud'homme, R. (1985). "Il futuro industriale di Venezia" In OECD (Ed.), Rapporto sulla rigenerazione industriale di Venezia. Paris: OECD.

Ramey, V.A., Vine, D.J. (2004) Tracking the Source of the Decline in GDP Volatility: An Analysis of the Automobile Industry, NBER Working Papers, https://www. ecb.europa.eu/events/pdf/conferences/ramey.pdf [Accessed: February 4, 2016]

Ritchie, J.R.B., Molinar, C.M.A., Frechtling, D.C. (2010) "Impacts of the World Recession and Economic Crisis on Tourism: North America", Journal of travel research, Vol. 49, No. 1, pp. 5-15, doi: 10.1177/0047287509353193.

Romer, D. (2012) Advanced macroeconomics, The Mcgraw-Hill Series in Economics, Business and Economics. 
Romer, C. (1999) "Changes in Business Cycles: Evidence and Explanations", Journal of Economic Perspectives, No. 13, pp. 23-44, doi: 10.3386/w6948.

Schumpeter, J. (1930) "Mitchell's Business Cycle", The Quarterly Journal of Economics, Vol. 45, No. 1, pp. 150-172, doi: 10.2307/1882530.

Schumpeter, J. (1939) Business Cycles: A Theoretical, Historical, and Statistical Analysis of the Capitalist Process, New York: McGraw-Hill.

Schumpeter, J. (1950) "Wesley Clair Mitchell (1874-1948)", The Quarterly Journal of Economics, Vol. 64, No. 1, pp. 139-155, doi: 10.2307/1881963.

Sherman, H., Kolk, D.X. (1996) Business Cycles and Forecasting, New York: Harper.

Sherman, H. (1991) The Business Cycle: Growth and Crisis Under Capitalism, Princeton, N.J.: Princeton University Press.

Singer, J.D., Willett, J.B. (1993) "It's About Time: Using Discrete-Time Survival Analysis to Study Duration and the Timing of Events", Journal of educational and behavioural statistics, Vol. 18, No. 2, pp. 155-195, doi: 10.3102/ 10769986018002155.

Smeral, E. (2010) "Impacts of the World Recession and Economic Crisis on Tourism: Forecasts and Potential Risks", Journal of Travel Research, Vol. 49, No. 1, pp. 31-38, doi: 10.1177/0047287509353192.

Stock, J.H., Watson, M.W. (2003) "Forecasting Output and Inflation: The Role of Asset Prices", Journal of Economic Literature, Vol. 41, No. 3, pp. 788-829, doi: $10.1257 /$ jel.41.3.788.

Word bank, http://data.worldbank.org/indicator [Accessed: May 31, 2017].

World Heritage Encyclopaedia, Timeline of the Great Recession, http://www. worldlibrary.org/article/WHEBN0040655549/Timeline\%20of\%20the $\% 20$ Great\%20Recession [Accessed: October 24, 2017]. 


\title{
Utjecaj turističke industrije i putovanja na veliku recesiju: višestruka analiza
} opstojnosti

\author{
Zdravko Šergo ${ }^{1}$, Jasmina Gržinićn ${ }^{2}$, Mirela Sučić Čevra ${ }^{3}$
}

\begin{abstract}
Sažetak
Je li zemlja s visokim stupnjem ovisnosti o turističkoj ekonomiji spremna podnijeti više rizika u recesiji? Zemljama u razvoju, prijelazom iz proizvodnih gospodarstava prema industrijama temeljenim na uslugama, ekonomsku stabilnost može pogoršati oslanjanje na turističku industriju, jer postaju podložnije utjecajima recesije zbog većih rizika. U ovom radu želimo naglasiti pozitivan utjecaj turističke specijalizacije u međunarodnoj ekonomiji na vjerojatnost tzv. velike recesije. Ovaj članak koristi analizu višestruke opstojnosti $i$ generaliziranu strukturu linearnih mješovitih modela (GLMM) kako bi se istražio utjecaj razvoja turizma na vjerojatnost recesijske učestalosti (rizik u smislu trajanja i težine). Korišteni su podatci prikupljeni u periodu od 2007. do 2013. godine iz 71 različite zemlje. Dokazano je da je učestalost recesije pozitivno povezana s različitim pokazateljima turističkog razvoja. Dva GLMM-a bila su prikladna za navedene podatke: logistička regresija i Poisson-ova distribucija. Rezultati obje regresije dokazuju da omjer između broja noćenja, rezidentnog stanovništva i putničkih usluga, kao postotka izvoza komercijalnih usluga, pozitivno utječe na vjerojatnost pojave recesijskog događaja (zemalja iz uzorka) i može je produbiti u smislu ozbiljnosti pojave, mjereno u mjesecima.
\end{abstract}

Ključne riječi: recesija, trajanje, rizik, turizam, analiza višestruke opstojnosti, GLLM

JEL klasifikacija: O1, F6

${ }_{1}$ Doktor znanosti, znanstveni savjetnik, Institut za poljoprivredu i turizam Poreč, Karla Huguesa 8, 52440 Poreč, Hrvatska, Tel.: +385 52408 300, Fax: +385 52431 659. Znanstveni interes: makroekonomija i primijenjena ekonometrija, ekonomski rast. E-mail: zdravko@iptpo.hr (osoba za kontakt).

2 Redovita profesorica, Sveučilište Jurja Dobrile u Puli, Fakultet ekonomije i turizma "Dr. Mijo Mirkovic" Pula, Hrvatska, Tel.: +385 52377 029, Fax: +385 52216416 . Znanstveni interes: turistički razvoj, turoperatori i turističke agencije, međunarodni turizam. E-mail: jasmina. grzinic@unipu.hr.

3 Doktorica znanosti, Tumlare Corporation Croatia, 10000 Zagreb, Hrvatska, Tel: +3851483 0337, Fax: +3851483 0067. Znanstveni interes: destinacijski menadžment, destinacijske menadžment kompanije.E-mail: Mirela.Sucic@tumlare.com. 
Zdravko Šergo, Jasmina Gržinić, Mirela Sučić Čevra • The tourism and travel industry...

\section{Appendices}


Zdravko Šergo, Jasmina Gržinić, Mirela Sučić Čevra • The tourism and travel industry... Zb. rad. Ekon. fak. Rij. • $2017 \cdot$ vol. $35 \cdot$ no. $2 \cdot 427-458$ 
Zdravko Šergo, Jasmina Gržinić, Mirela Sučić Čevra • The tourism and travel industry...

Figure A1: Tourism employment as a percentage in whole economy employment vs. Recession

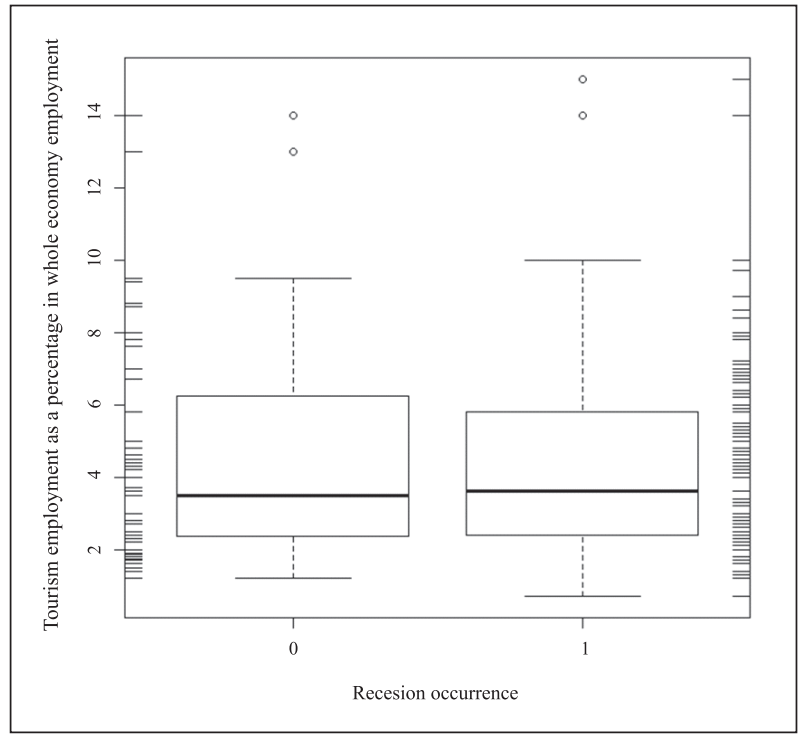

Note: " $1 "=$ recession, " 0 " = expansion

Source: Author's computation

Figure A2: Tourism saturation per capita vs. Recession

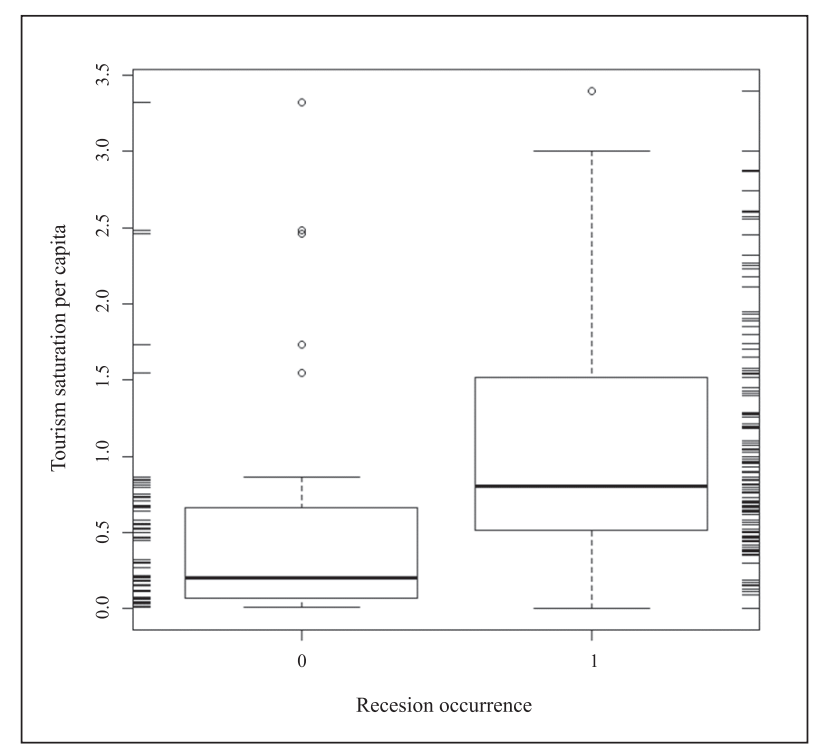

Note: " 1 " = recession, " 0 " = expansion

Source: Author's computation 
Figure A3: Recession duration vs. Recession

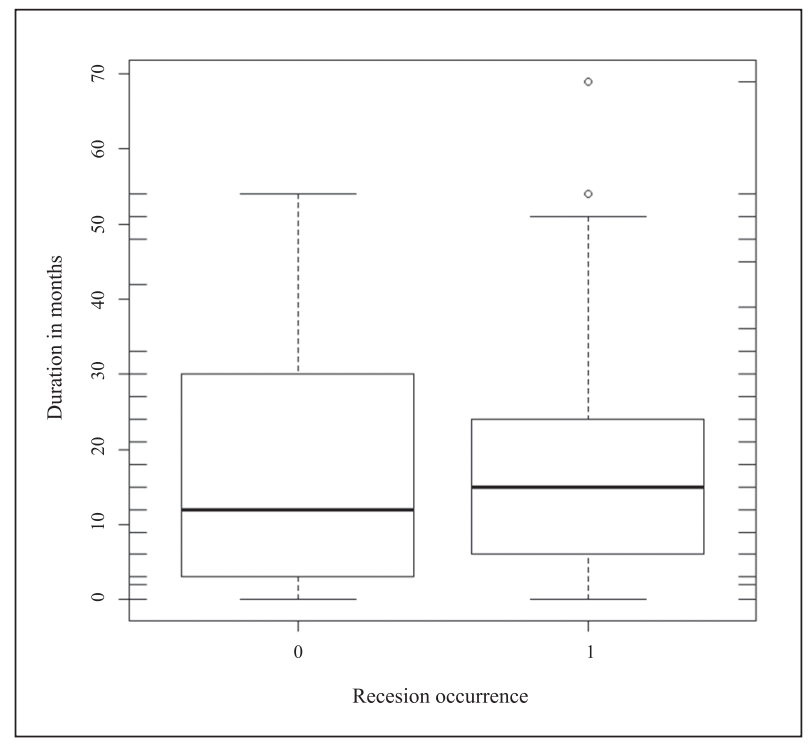

Note: "1" = recession, "0" = expansion

Source: Author's computation

Figure A4: International tourism receipts vs. Recession

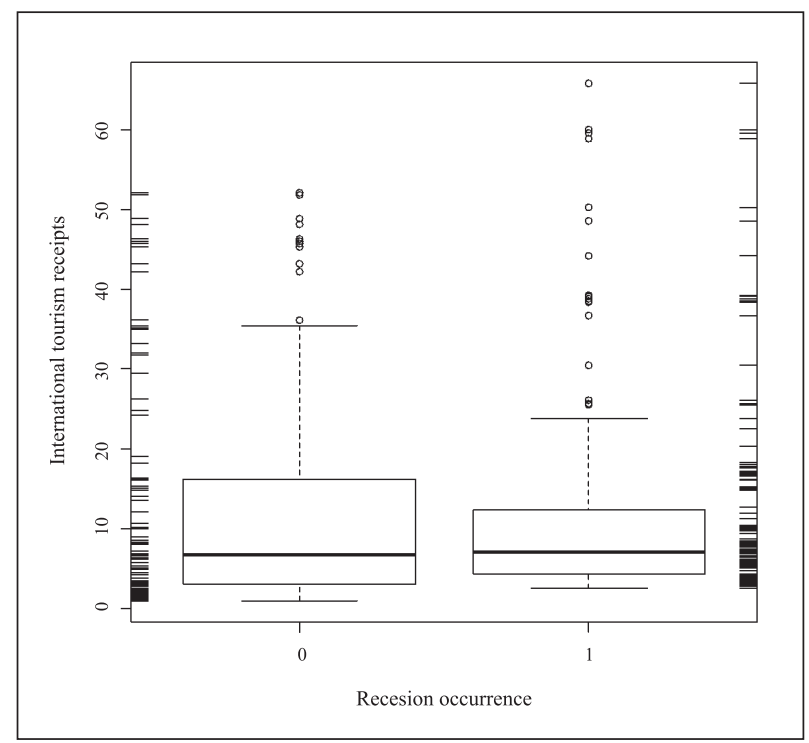

Note: "1" = recession, "0" = expansion

Source: Author's computation 
Zdravko Šergo, Jasmina Gržinić, Mirela Sučić Čevra • The tourism and travel industry...

Figure A5: Travel services vs. Recession

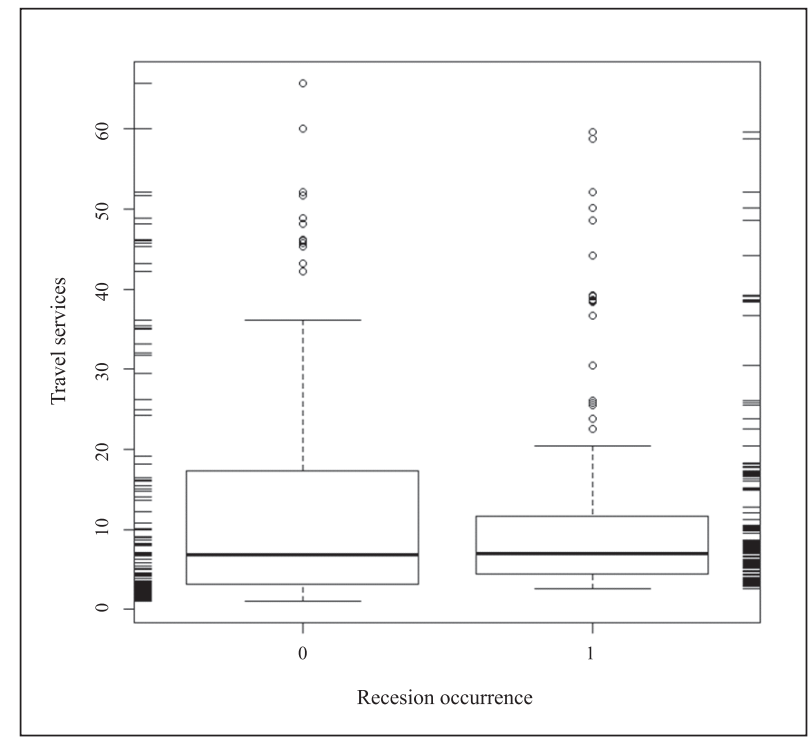

Note: " 1 " = recession, " 0 " = expansion

Source: Author's computation

Figure A6: Air passengers per capita vs. Recession

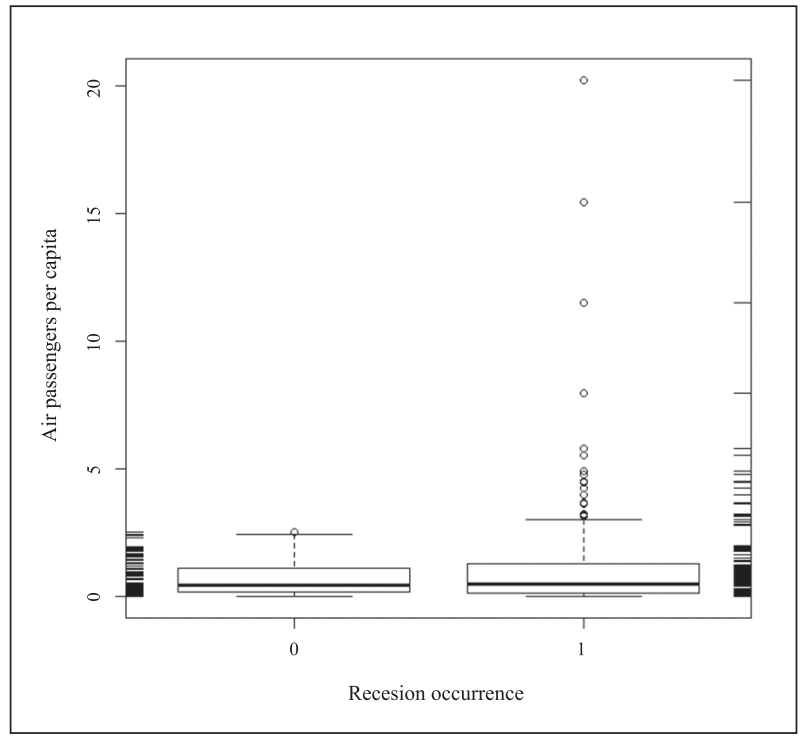

Note: " 1 " = recession, " 0 " = expansion

Source: Author's computation 
Zdravko Šergo, Jasmina Gržinić, Mirela Sučić Čevra • The tourism and travel industry... Zb. rad. Ekon. fak. Rij. • 2017 • vol. $35 \cdot$ no. $2 \cdot 427-458$

Figure A7: Coastal border length vs. Recession



Note: "1" = recession, " 0 " = expansion

Source: Author's computation 